\title{
On the genesis of aluminum-rich speleothems in a granite cave of NW Spain
}

\author{
Jorge Sanjurjo-Sánchez (D) 1*, Carlos Arce Chamorro (D) ${ }^{1}$, Juan R. Vidal Romaní (D) ${ }^{1}$, \\ Marcos Vaqueiro-Rodríguez (D) ${ }^{1}$, Victor Barrientos (D) ${ }^{1}$, and Joeri Kaal (D) ${ }^{2}$ \\ ${ }^{1}$ Instituto Universitario de Geología "Isidro Parga Pondal", Universidade da Coruña, ESCI, Campus de Elviña, 15071, A Coruña, Spain \\ ${ }^{2}$ Pyrolyscience, Plaza Ciudad de Viena 6, 28040 Madrid, Spain
}

\begin{abstract}
Granite massifs often contain caves, with dimensions ranging from a few meters up to 1,000 $\mathrm{m}$, also referred to as pseudokarst. The speleothems in such caves are mostly composed of either Si-rich (commonly opal-A) or Al-rich authigenic mineraloids. Whereas the formation and geochemical composition of opal-A biospeleothems have been studied and are fairly well understood, knowledge on the Al-rich analogues is scarce. This work reports for the first time a study on the composition, accretion process, age and growth rate of an Al-rich speleothem type flowstone from the A Trapa Cave System (Galicia, NW Spain), developed in a granite cave. To understand the growth process, trickling water was analyzed and the deposition environment inside the cave was characterized. We found that the speleothems are alternating Si- and Al-rich layered deposits formed between 1,635 \pm 75 and 1,243 \pm 58 cal $\mathrm{BP}$ by percolating water that carries underground mineral grains, dissolved ions, and organic matter from soil and the weathered bedrock above the cave.
\end{abstract}

$\begin{array}{ll}\text { Keywords: } & \text { pseudokarst, cave minerals, organic matter, Al-rich speleothems } \\ & \text { Received } 13 \text { October 2020; Revised } 14 \text { February 2021; Accepted } 14 \text { February } 2021\end{array}$

Citation: Sanjurjo-Sánchez J., Arce Chamorro C., Vidal Romaní J.R., Vaqueiro-Rodríguez M., Barrientos V. and Kaal J., 2021. On the genesis of aluminum-rich speleothems in a granite cave of NW Spain. International Journal of Speleology, 50 (1), 25-40. Tampa, FL (USA) ISSN 0392-6672 https://doi.org/10.5038/1827-806X.50.1.2358

\section{INTRODUCTION}

Caves in non-soluble rocks are referred to as pseudokarst, and in general terms are considerably smaller than those in limestone caves. The study of cavities developed in granite rocks has particular interests, such as the growth microorganisms, the development of speleothems, or the presence of archeological objects (Twidale \& Vidal Romaní, 2005; Vidal Romaní \& Vaqueiro, 2007; SanjurjoSánchez et al., 2013). Granite caves are relatively frequent (Chabert \& Courbon, 1997). Presently, the longest known cave is the T.S.O.D. (New York, USA) reaching almost $4 \mathrm{~km}$ (Chabert \& Courbon, 1997; Vidal-Romani \& Vaqueiro, 2007). One of the most interesting features of granite caves is the formation of speleothems related to microbiological activity (VidalRomaní et al., 2015; Riquelme et al., 2015; Lavoie et al., 2017; González-López, 2018; González-Pimentel et al., 2018; Filippi et al., 2020). Even though such speleothems have rarely been studied, they may be valuable archives of environmental change, and form a habitat of unknown microbial species (Vidal-Romani et al., 2010, 2015; Sanjurjo-Sánchez \& Vidal Romaní, 2011; Filippi et al., 2020).

Due to the low porosity of fresh granitic rocks, the opened fractures control the influence on weathering, increasing permeability and porosity (Gustafson \& Krásny, 1993; Zhang et al., 2002). Thus, the growth of speleothems in granite caves is related to water pathways (percolation or seepage) through the fissures of the host rock, and the resulting cave morphology is linked to the massif's structure. Rock weathering occurs in relation to biological activity resulting in the formation of small-sized speleothems linked to water fluxes from the ceiling, floor, and walls of the caves (Vidal Romani et al., 2010, 2015; Filippi et al., 2020).

\section{Speleothems in granite caves}

Several types of speleothems in granite caves have been studied and classified according to their shape, genesis, and composition. In general, the size, shape, and genesis of speleothems are controlled by their composition. Opal-A speleothems and Alrich speleothems with organic inclusions are the most frequent (Vidal Romaní et al., 1998, 2003, 
2010; González-López, 2018; González-Pimentel et al., 2018; Filippi et al., 2020). The development of opal-A speleothems is linked to biological processes (Aubrecht, 2008; Vidal Romaní et al., 2010, 2015; Barton et al., 2014; Sauro et al., 2018). Less attention has been paid to the Al-rich speleothems, known as aluminium-bearing organic compounds speleothems (AOS), "pigotite" (Johnston, 1840; Vidal Romaní et al., 2010; Filippi et al., 2020), or allophane speleothems (Hill \& Forti, 1995; Filippi et al., 2020). They were initially described in sea caves of Cornwall (UK) and previously referred as "pigotite" by mineralogists (Johnston, 1840), although there is no precise information on their chemical and mineralogical composition. This is because this type of speleothems is composed of poorly-crystalline ("amorphous") materials that are originally highly hydrated, so that the sample preparation process (i.e., dehydration) for electron microscope observation, implies the virtual destruction of the sample (Vidal Romani et al., 2010). Johnston (1840) proposed that these speleothems are generated by the decay of moist moorlands that overlay the caves, through slow infiltration. The speleothems can be as long as $1 \mathrm{~m}$, and are formed by accretion of water-saturated layers composed of alternating Al-rich and Si-rich materials. These seem to correspond to seasonal variations in the environmental parameters accumulations (Vidal Romani et al., 2010). AOS are frequent in granite caves, being reported all around the World (Hill \& Forti, 1995; Vidal Romani et al., 2010; Filippi et al., 2020), where they are often found as stalactites, stalagmites, columns, and flowstones (Fig. 1). Investigations on the composition, structure, the growth rate of AOS speleothems, and their ages are scarce. Indeed, Filippi et al. (2020) reported that "it is difficult to find a more precise characteristic of pigotite in the existing literature". Regarding the formation rates, the only dates obtained in a speleothem from O Folón System and A Trapa Cave System (Galicia, Spain) by radiocarbon analyses of organic constituents ranged from 1,500 to 3,000 years BP. This is a growth rate that appears to be higher than that of calcite speleothems in limestone caves (Vidal Romani et al., 2010). Organic matter is relatively abundant in the AOS, ranging from 1 to $10 \%$ (Vidal Romani et al., 2010; Filippi et al., 2020), but this organic matter has not been investigated in detail to date.
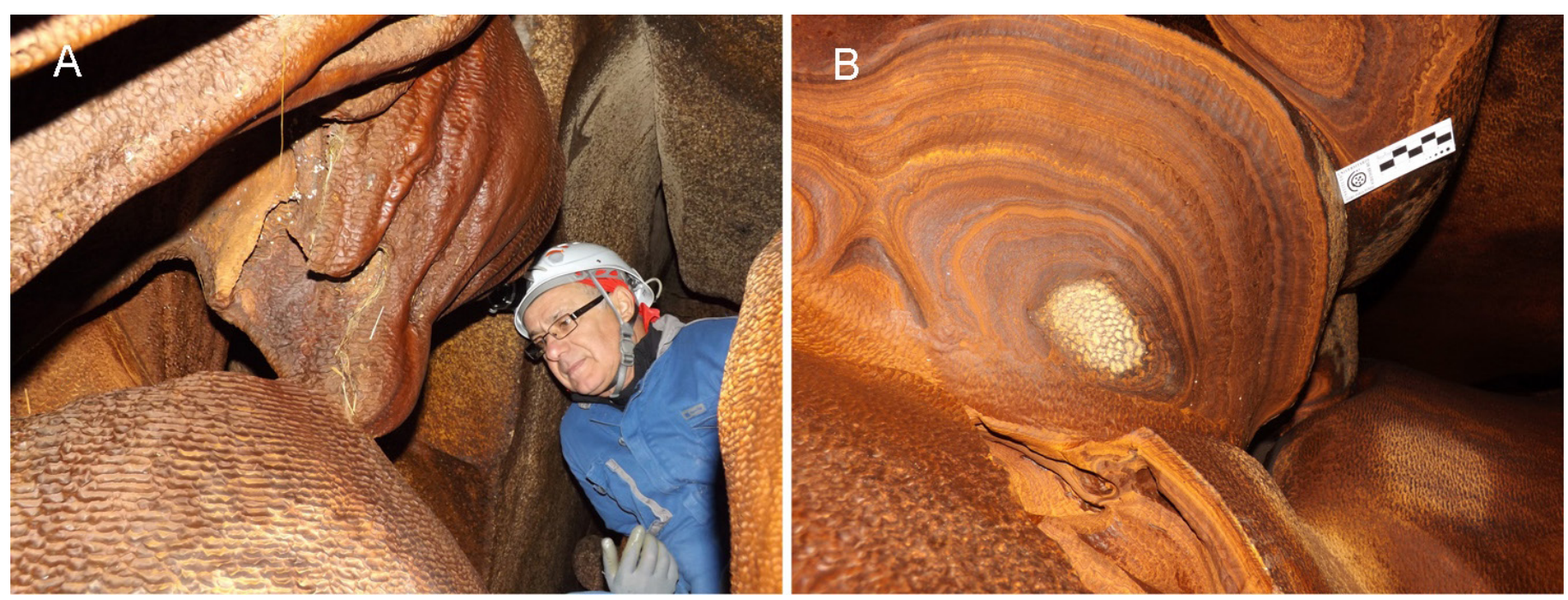

Fig. 1. Examples of Al-rich speleothems in the A Trapa Cave System. A) Flowstones; B) Detail of a cross-section of a naturally broken flowstone.

In the present study, we investigate AOS in a system of granite caves. In particular, we provide novel information on (1) the chemical composition of the speleothems, (2) the content and characteristics of the organic matter, and (3) the growth rates. This information is then used in combination with radiocarbon ages to evaluate the potential of these speleothems as environmental archives. Environmental conditions (temperature regime) inside the cave were monitored at the sampling site and nearby, to better understand the growth of speleothems and assess paleoclimatic reconstructions (Fairchild \& Baker, 2012).

\section{Study area and cave description}

We focus on a deposit from A Trapa Cave System (Tui, Pontevedra, NW Spain, Lat. 42.3 N, Long. -8.82 E), close to the Portuguese border. The studied cave system formed in a granitic-gneissic rock and has a water course that flows through part of it. This is one of the most important European granite caves, being the second longest $(1,590 \mathrm{~m})$ after Boda Grottor Cave (Imgesund, Sweden). The cave is located in Serra do Galiñeiro, where altitudes range between 600 and $700 \mathrm{~m}$ a.s.1. and is in the close proximity of the Atlantic coast. The rock is a S-type granite intruded in the Upper Carboniferous (IGME, 1971; Lagarde et al., 1992) and the landform was formed during the Cenozoic (Vidal Romaní, 1989).

The A Trapa Cave System is a group of granite cavities that drains underground the watercourse of the San Simón River in a section of 250 m, with 102 $m$ altitudinal difference between the sinkhole and the emergence (mean watercourse slope $27^{\circ}$ ). It is associated with a reverse fault of $\mathrm{N} 125^{\circ} \mathrm{E}$ direction, which coincides with the main underground channel. During peak discharge of the river (winter) a surface water flowing channel is observed. This channel is dry during the dry season (summer), with the underground channel within the cave the only one 
flowing. The complete passages and galleries of the cave were mapped with a difference in height of $94 \mathrm{~m}$ between the highest and the lowest levels (Fig. 2A). The sector called Féveros, located at the middle section of the system (depths referred to the sinkhole between
25 and $50 \mathrm{~m}$ ), shows the most complete sequence of forms and speleothems. For more information on the geological background and morphology of the A Trapa Cave System, refer to Vaqueiro-Rodriguez et al. (2015).
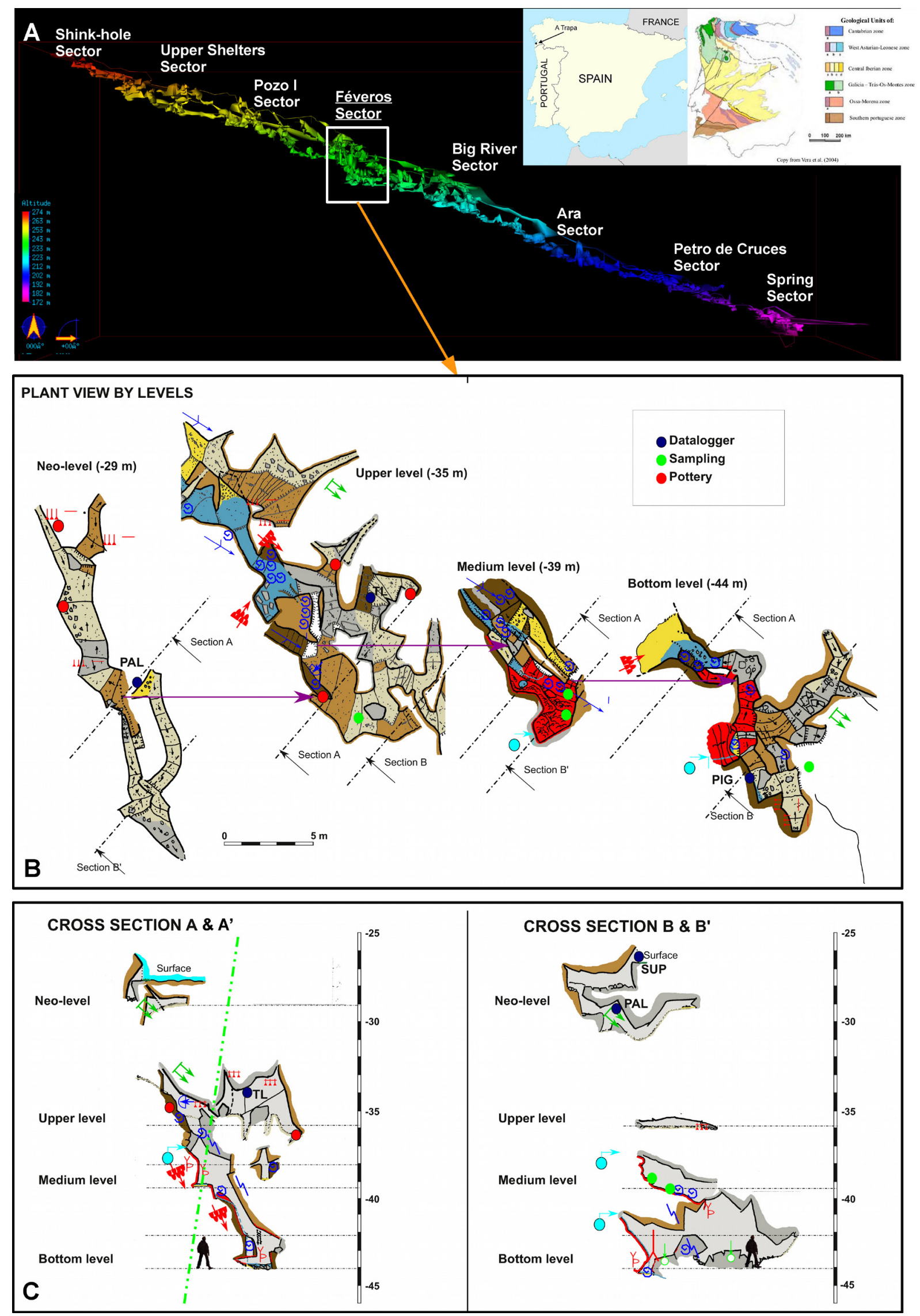

Fig. 2. A) Map of the A Trapa Cave System (with inset of cave location and geological map of Spain); B) Plant view of the cave in different levels with the position of data loggers, sample sites, and pottery fragments; C) Cross sections A-A' and B-B' showing in detail the location of the studied speleothem. 


\section{METHODS}

\section{Monitoring of environmental conditions}

The thermal dynamics of the cave were modeled through temperature records obtained with several data loggers distributed at four different levels: SUP (0.2 $\mathrm{m}$ from the entrance and $25 \mathrm{~m}$ below the surface), PAL $(3.6 \mathrm{~m}$ from the entrance and $28 \mathrm{~m}$ below the surface), TL (5.65 $\mathrm{m}$ from the entrance height and 34 $\mathrm{m}$ below the surface) and PIG (7.1 $\mathrm{m}$ from the entrance and $44 \mathrm{~m}$ below the surface). Data were recorded every hour during a period of 2 years and 6 months.

External temperature data were obtained from the nearest meteorological stations to the cave (Mount Aloia Station Lat. 42.08 N, Lon. -8.68 E; 2.48 km and Areas Station Lat. 42.03 N, Lon. -8.67 E; 8.43 $\mathrm{km}$ ) and compared with the cave data. In this area, air temperature conditions strongly change over short distances due to seaside effect and relief. The daily mean temperatures from Surface Air Temperature (SAT) at $0.1 \mathrm{~m}$ and Ground Surface Temperature (GST) at 0.1 $\mathrm{m}$ below surface at the nearest meteorological station and the daily mean cave temperature were compared.

\section{Sampling procedure}

A flowstone with an approximate thickness of 12.3 $\mathrm{cm}$ was carefully collected and transported to the laboratory, where it was preserved in a closed bag in the dark at $4^{\circ} \mathrm{C}$, to avoid drying, which would cause the sample to disintegrate easily into powder.

A complete flowstone similar but smaller than the one shown in Figure 1 was studied. The flowstone was soft, similar to a clay deposit. A subsample of the speleothem (comprising several bands) was then taken for bulk analyses (chemical and mineralogical), whereas another part was sliced to obtain a longitudinal cross section. Figure 3 shows bands that form a rhythmic-like structure. This pattern of approximately 30 bands reflects the stratification and accretion process of the speleothem. Each band was sampled, using a scalpel, under the stereoscopic microscope. Two of the bands (P07 and P21) were also separated for analyses of organic constituents. These bands were selected as representative of two different deposition stages, based on their yellow-brown appearance, average chemical and mineralogical composition, and on sample availability.

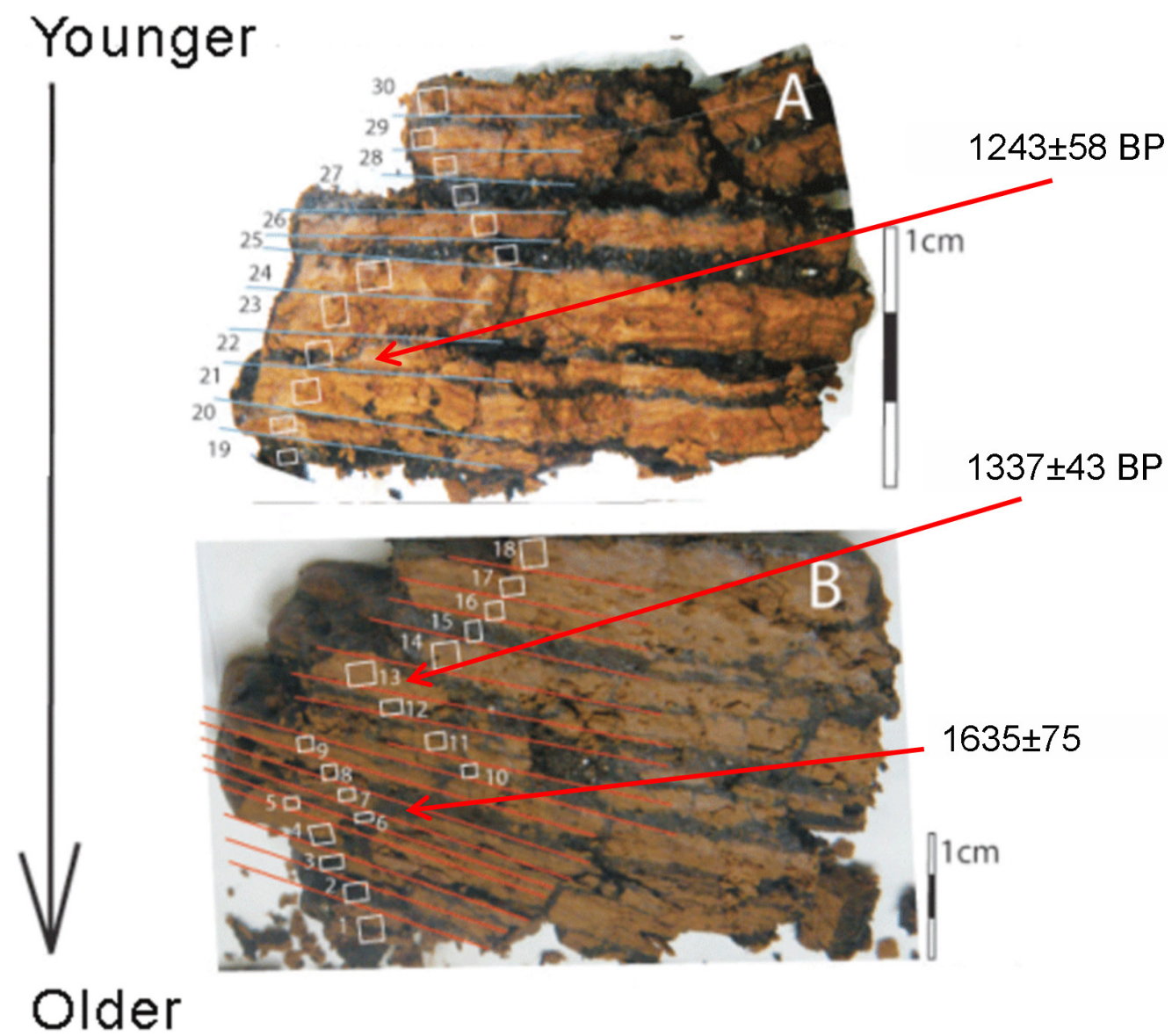

Fig. 3. Section of the laminated flowstone showing the radiocarbon ages. Numbers refer to sample labels used in the text (e.g., P07, P21). The speleothem broke during sampling into two fragments (A and B).

Water samples associated with the speleothem were also collected for analyses. One represents drip water trickling from above the speleothem (ATP-1) whereas the other is water from the cave floor below the speleothem (ATP-2).

Finally, a sample of soil overlying the cave was also collected. This is a very thin soil cover $(3-4 \mathrm{~cm})$ with scarce vegetation mostly composed of mosses, and with unweathered granite directly underneath.

\section{Petrographic and mineralogical analyses}

The longitudinal section of the sampled speleothem was divided in two parts. One part was dried under vacuum conditions and soaked with an epoxy resin, and then cut to obtain both polished surfaces to be observed using a Nikon 512005 optical polarizing stereoscopic microscope and for preparation of thin sections for petrographic analyses. A Nikon H550S magnifier was also used to observe macroscopic details 
of the texture of the sample. Microscopic observations provide information on the size and arrangement of the bands (or rhythms), on texture and the mineral components (major, minor and trace minerals) and speleothem genesis.

For instrumental analyses a portion of the dried samples was separated and homogenized. Mineralogical composition was also determined by means of X-ray diffraction (XRD) of bulk samples taken from the studied speleothem. Samples were analyzed using a D5000 Siemens powder diffractometer with $\mathrm{Ni}$-filtered $\mathrm{CuKa}$ radiation. Measurements were performed at $40 \mathrm{kV}, 30 \mathrm{~mA}$, with a step size of $0.050^{\circ}$ and step time of $2.5 \mathrm{~s}$, a $2 \mathrm{q}$ range of $2-80^{\circ}$. Bulk samples showed very small peaks that correspond to quartz. To check for possible clays, poorly-crystalline and scarce minerals, fine grains were separated (by sedimentation) and analyzed by XRD.

In order to identify poorly crystalline phases, Fourier-Transform Infrared Spectroscopy (FTIR) in attenuated total reflectance (ATR) mode was applied to powders of bulk samples (100 mg) using a Bruker Vector 22 spectrometer equipped with a diamond crystal (Golden Gate, Specac), where pellets of sample and reagent-grade $\mathrm{KBr}$ were pressed to form a transparent pellet with a diameter and thickness of $80 \mathrm{~mm}$ and $1 \mathrm{~mm}$, respectively. The spectra were obtained for the $400-4000 \mathrm{~cm}^{-1}$ range at a spectral resolution of $2 \mathrm{~cm}^{-1}$.

Thermal analyses were used to obtain complementary information including thermogravimetric (TGA) and differential thermal analysis (DTA). Between 30 and 50 $\mathrm{mg}$ of the powdered samples were placed in alumina cups in a Thermal Analysis SDT2960 instrument. The samples were heated to $1,100^{\circ} \mathrm{C}$ at a rate of $10^{\circ} \mathrm{C} /$ min, under oxidizing conditions. All the analyses were performed at the University of A Coruña.

\section{Elemental composition of inorganic matter}

It is not possible to observe a speleothem crosssection with Scanning Electron Microscopy (SEM) and carry out analyses by Dispersive Energy X-ray Spectroscopy (EDS) because the sample must be dehydrated for observation and the dried sample breaks down into a powder (as reported in Vidal Romani et al., 2010). An attempt was made on thin sections but no layers were observed under the SEM, and EDS only provided signals of $\mathrm{C}, \mathrm{Si}$, and $\mathrm{Al}$, without meaningful variations between layers. Therefore, chemical analyses were used to assess the content of elements in the bulk speleothem, granite rock, and a soil sample. Additionally, subsamples from 30 individual bands, obtained using a stereoscopic microscope and a scalpel followed by drying, grinding, and homogenization, were analyzed to study the variability across the entire speleothem (Fig. 3). The major and minor element composition was assessed by X-Ray Fluorescence Spectrometry (XRF) using a S4 Pioneer fluorescence spectrometer (Bruker-Nonius) of wavelength dispersion under helium purge on powdered samples (>63 $\mathrm{mm}$ size) at the University of A Coruña.

\section{Characterization of organic matter}

The elemental composition of the organic matter (C, H, N, and S) in the powdered bulk sample of the speleothem, and individual bands, was measured by a ThermoQuest Flash EA 1112 and a Carlo Erba (model EA 1108) instruments at the University of A Coruña. Approximately $5 \mathrm{mg}$ of sample was used. The first analysis (ThermoQuest device) consisted of combustion in $\mathrm{Ag}$ capsules to obtain total $\mathrm{C}, \mathrm{H}$, $\mathrm{N}$, and $\mathrm{S}$. The second analysis (Carlo Erba device) removed inorganic carbon with $\mathrm{HCl}$ followed by combustion to determine organic carbon. More details of the procedures are described in Nieuwenhuize et al. (1994).

The molecular composition of the organic matter was assessed using analytical pyrolysis coupled to gas chromatography and mass spectrometry (Py-GCMS). We analyzed samples of selected bands (P07 and P21), which were considered representative of early and late formation. Initial analysis of untreated bulk samples provided unsatisfactory pyrolysis chromatograms, probably due to low organic matter content and interference of minerals (catalyzing or inhibiting different pyrolytic pathways, and retention of pyrolysis products) (Miltner \& Zech, 1997). Therefore, we applied mild acid etching to remove reactive mineral constituents that may interfere with the pyrolysis reactions, following the recommendations of $2 \% \mathrm{HF}$ treatment by Zegouagh et al. (2004). Approximately $1 \mathrm{mg}$ of HF-treated sample was inserted into fire-polished quartz tubes positioned with quartz wool. The pyrolysis of samples was performed at $750^{\circ} \mathrm{C}$ for 10 seconds with a heating rate of $10^{\circ} \mathrm{C} / \mathrm{ms}$ using a Pyroprobe 5250 resistive heating Pt-filament instrument from CDS Analytical. The pyrolysis products were transferred into a $6890 \mathrm{~N}$ gas chromatograph (Agilent Technologies) by He flow (1 $\mathrm{ml} / \mathrm{min}$ ), separated on a HP-5MS polysiloxanebased column (temperature program $60-325^{\circ} \mathrm{C}$ at $20^{\circ} \mathrm{C} / \mathrm{min}, 5 \mathrm{~min}$ dwell time) and identified using an Agilent 5975B mass spectrometer operating in $70 \mathrm{eV}$ electron impact mode. The main peaks were listed and identified on the basis of the NIST '05 library and compared with previous samples analyzed under the same analytical conditions. This resulted in a list of 141 pyrolysis products, which were semiquantified using their dominant fragment ions $(\mathrm{m} / \mathrm{z})$. Relative proportions were calculated as percentage of total quantified peak area (\% TQPA). This is a semi-quantitative exercise that improves the level of interpretation in comparison with visual inspection of pyrolysis chromatograms.

\section{Water analyses}

The water $\mathrm{pH}$ was measured with a Hamilton electrode mounted on a Metrohm Titrando 808 equipment. Selected anions $\left(\mathrm{F}^{-}, \mathrm{Cl}^{-}, \mathrm{NO}_{2}, \mathrm{NO}_{3}^{-}, \mathrm{Br}^{-}, \mathrm{PO}_{4}{ }^{3-}\right.$, and $\mathrm{SO}_{4}{ }^{2-}$ ) were determined by ion chromatography using an 850 Professional IC Metrohm. Furthermore, $\mathrm{NH}_{4}^{+}$ was also determined by colorimetry with a Labmedics QquaKem 205. The total organic carbon concentration (TOC) was estimated from total and inorganic $\mathrm{C}$ contents and dissolved organic C (DOC) determinate 
from the difference between total DOC and dissolved inorganic C measured in a Shimadzu TOC 5000A after filtration with a Millex-HN membrane $(0.45$ $\mu \mathrm{m}$, Millipore). Finally, total $\mathrm{P}$ content and metallic elements (Mg, Si, Al, Mn, and Fe) were measured by Inductively Coupled Plasma - Mass Spectrometry (ICP-MS) using a Magnetic Sector Mass Spectrometer (Thermo Finnigan ELEMENTXR), at the University of A Coruña.

\section{Radiocarbon dating}

Three selected bands spanning the whole speleothem (P7, P13, and P22 in Fig. 3) were separated after organic carbon analyses. About $2 \mathrm{~g}$ of the samples were removed with a spatula avoiding the band edges, dried, and kept in Eppendorf tubes. A standard acid-base-acid treatment and graphitization process was conducted in the labs of Beta Analytic, where the radiocarbon dating was performed using an accelerator mass spectrometer (AMS). Ages were calibrated with the INTCAL13 database (Reimer et al., 2013) and Oxcal 4.1 (Bronk Ramsey \& Lee, 2013).

\section{RESULTS AND DISCUSSION}

\section{Cave environment}

Table 1 summarizes the time data in hours in each recording station, with mean, maximum, minimum temperatures and the temperature range (one measurement per hour). The data shows a quasi-synchronous behavior with outer climatic oscillations (Fig. 4). The temperature follows, in an attenuated manner, the outside variations at each studied cave level. However, this behavior does not correspond to classical thermal diffusion models. We attribute this to the fact that A Trapa is a cave of blocks (large blocks), consisting of irregular galleries, and irregular cave walls. Therefore, the underground temperature is, as expected, the result of convective and diffusive processes, with a thermal unbalance between the surface and the cave (Badino, 2004). Since the cave environment reflects the outer climate, it is expected that the speleothems reflect these variations. However, the small topoclimatic changes observed nearby the studied flowstone ( $\mathrm{T}=7-17^{\circ} \mathrm{C}$ and high relative humidity) prevent the speleothem from drying. Such ranges are not very different compare to other limestone and pseudokarst caves (Veiten et al., 2016; Kasing \& Lenart, 2020). Condensation on the cave walls and surfaces supply additional water that keep the speleothem hydrated. This is crucial for the preservation of the flowstone and the use of both siliciclastic components and organic matter as possible environmental records, likewise in calcite speleothems.

Table 1. Datalogger stations, location, and major statistical data of the obtained temperature measurements.

\begin{tabular}{|l|c|c|c|c|c|c|c|}
\hline Station & $\begin{array}{c}\text { Recorded } \\
\text { time (h) }\end{array}$ & Local depth (m) & $\begin{array}{c}\text { Depth (Referred to the } \\
\text { swallow hole) (m) }\end{array}$ & $\begin{array}{c}\text { Max. Temp. } \\
\left(\mathbf{(}^{\circ} \mathbf{C}\right)\end{array}$ & $\begin{array}{c}\text { Min. Temp. } \\
\left(\mathbf{(}^{\circ} \mathbf{C}\right)\end{array}$ & $\begin{array}{c}\text { Temp. Range } \\
\left({ }^{\circ} \mathbf{C}\right)\end{array}$ & $\begin{array}{c}\text { Mean Temp. } \\
\left({ }^{\circ} \mathbf{C}\right)\end{array}$ \\
\hline SUP & 577 & 0.2000 & 25 & 20.5 & 8 & 12.5 & 12.14 \\
\hline PAL & 4871 & 3.6147 & 28 & 21.5 & 3.5 & 18 & 10.47 \\
\hline TL & 11927 & 5.6477 & 34 & 18 & 6.5 & 11.5 & 11.84 \\
\hline PIG & 8501 & 7.1010 & 44 & 17 & 6 & 11 & 12.63 \\
\hline
\end{tabular}

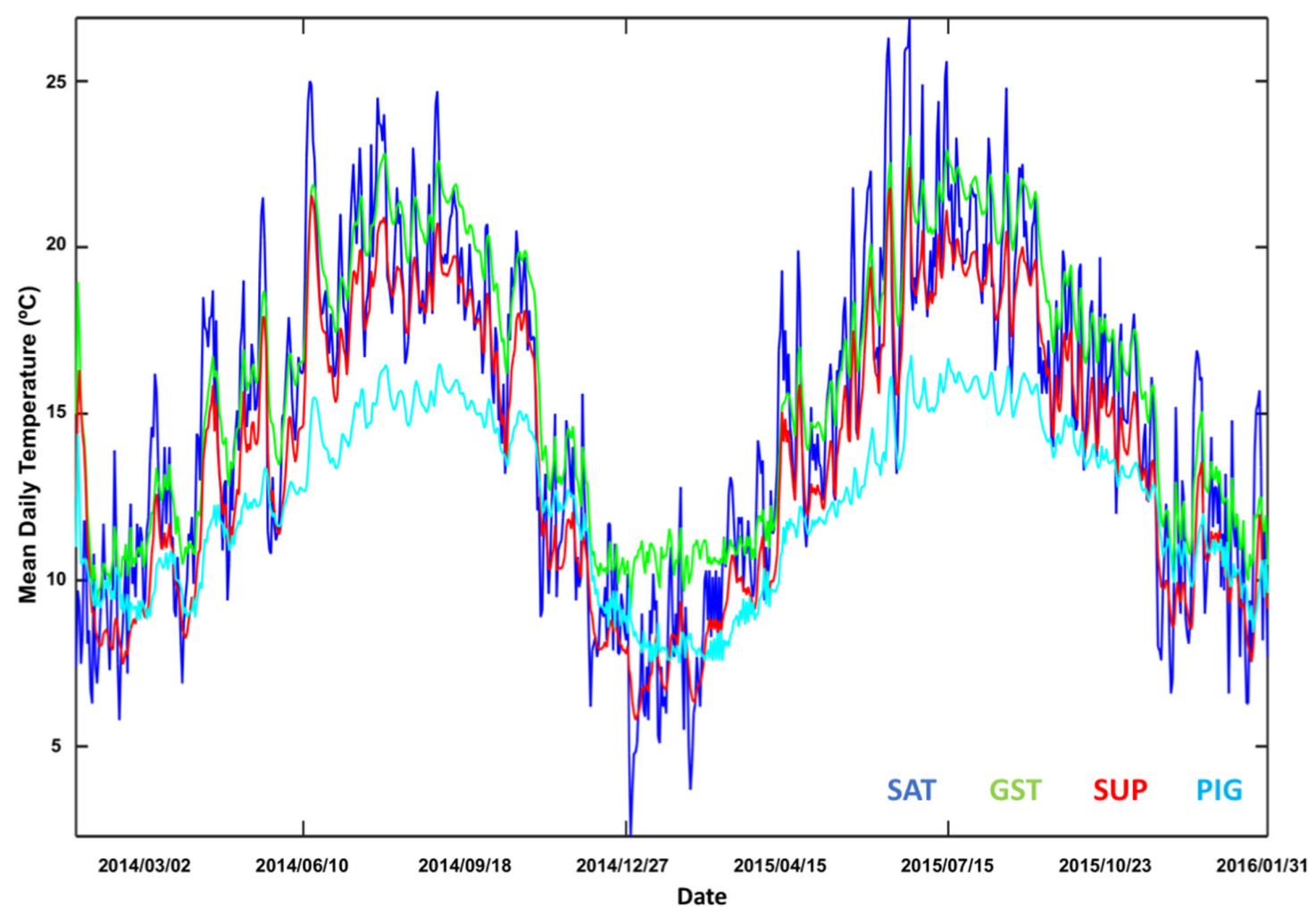

Fig. 4. Temperature values recorded over 30 months (2014-2016) at surface (SAT and GST) and in the cave at $0.2 \mathrm{~m}$ (SUP) and $7.1 \mathrm{~m}$ (PIG) below surface, respectively. The speleothem was collected near PIG. 


\section{Structure and mineralogy of the speleothem}

The studied speleothem consists of alternating bands of yellow and brown with brown boundaries. Macroscopically, the bands can be easily observed (Fig. 3). The thickness of yellow bands ranges from 0.2 to $1.0 \mathrm{~cm}$, whereas the black ones are between 0.2 and $0.5 \mathrm{~cm}$. Under the stereoscopic microscope, the yellow bands appear to be composed of very fine wavy laminae whose color alternate from yellow to brown (Fig. 5A). These wavy features are not observed in the black bands. Under the petrographic microscope, thin sections show that they are alternating yellow and red thin laminae that form the bands (Fig. 5B). The laminae are mostly formed of amorphous material. Patches of black material, probably corresponding to organic matter are also observed (Fig. 5B). The thickness of such laminae ranges from 17 to $33 \mathrm{~mm}$. Counting of bands showed that their frequency ranges between $30-40$ and 50-60 laminae/mm.

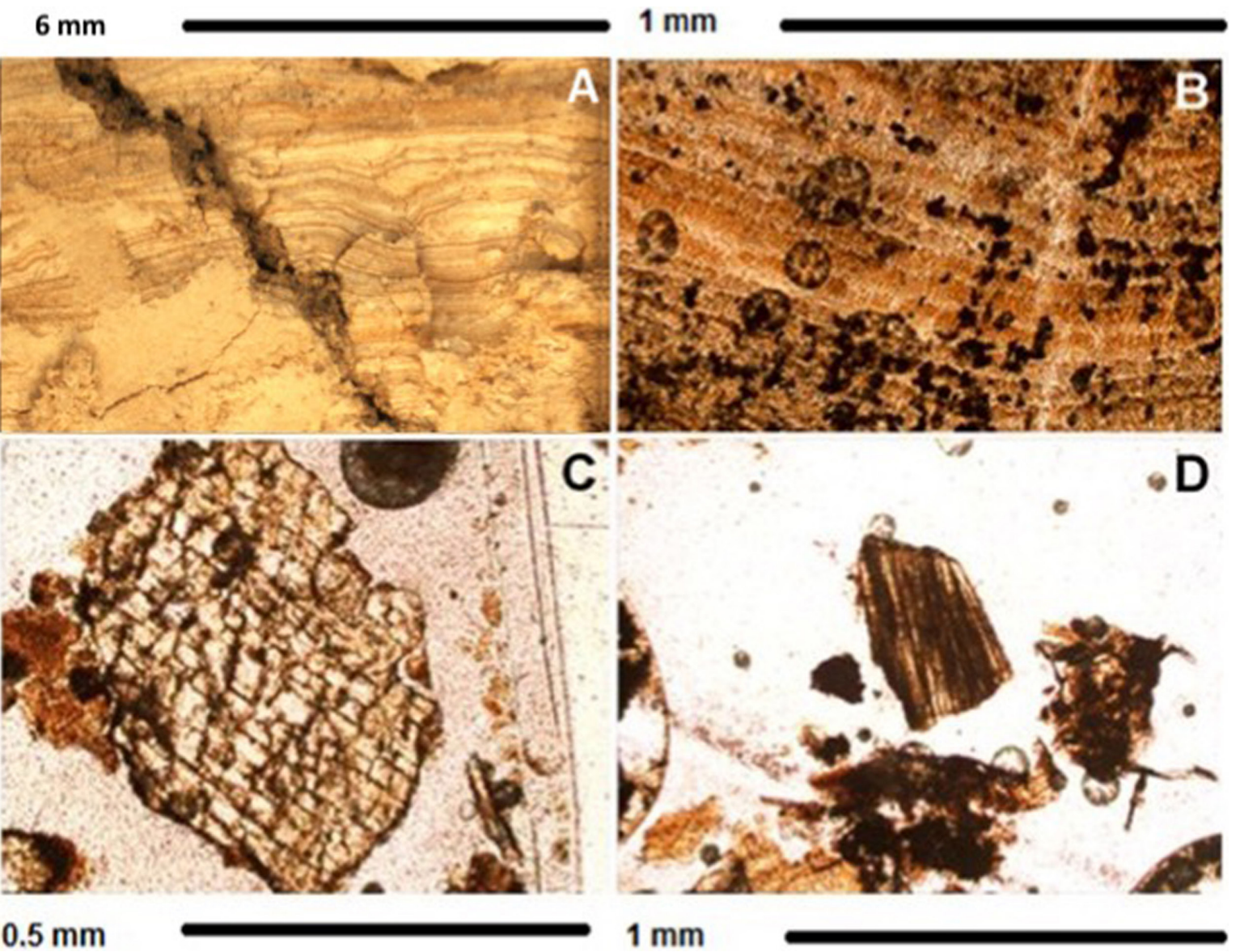

Fig. 5. Microscope images of the studied speleothem. A) Wavy thin laminae observed under stereoscopic microscope; B) Petrographic microscope image of thin section featuring alternating bands from the central part of the cross section showed in Figure $5 \mathrm{~A}$; C) Close up view of an amphibole silt size mineral; D) Detail of silt-sized biotite.

Thin sections provided evidence of the presence of some silt size grains of chloritized amphibole (hornblende; Fig. 5C), biotite (Fig. 5D), pyroxene (ortho and clino), zircon, quartz, and feldspar (mostly plagioclase). These mineral grains were likely transported by water from the soil overlying the cave (weathered granite) and incorporated in the flowstone's layers. Crystalline authigenic minerals are not present.

In an attempt to quantify detrital grains, the 30 separated bands of the sample were sieved. The analysis showed that most of the material (60 to $85 \%)$ corresponds to fine-grained size with a diameter $<0.06 \mathrm{~mm}$, except for the black bands, in which ca. $95 \%$ of the material consists of silt size minerals. The remaining fraction corresponds to fine sand (diameter $<0.3 \mathrm{~mm}$ ), whereas material $>0.3 \mathrm{~mm}$ was scarce, from 0.3 to $7 \%$.

XRD analyses only indicate quartz peaks, which is why fine grains were also separated and analyzed to identify clay and poorly crystalline phases. No evidence of other crystalline minerals than quartz exist, which is in agreement with observations of thin sections under petrographic microscope. In previous studies, Vidal-Romaní et al. (2010) and Filippi et al. (2020) reported the difficulty of analyzing this kind of speleothems, due to their amorphous nature.

FTIR performed on the fine-grained fraction of the bulk flowstone (Fig. 6) showed several bands with $\mathrm{C}$, $\mathrm{N}$, and $\mathrm{S}$ (wavelengths 2,400-1,995, 2,650, and 1,350 $\left.\mathrm{cm}^{-1}\right)$, other organic compounds $(3,500-3,200,2,920-$ 2,505, and 1,000-910 $\left.\mathrm{cm}^{-1}\right), \mathrm{Al}-\mathrm{O}, \mathrm{Fe}-\mathrm{O}$, and $\mathrm{Fe}-\mathrm{OH}$ bonds (700-463 $\left.\mathrm{cm}^{-1}\right)$ and the possible presence of opal-A $\left(1,105 \mathrm{~cm}^{-1}\right) \mathrm{OH}$ bonds are abundant probably due to the Al-hydroxides $\left(3,340 \mathrm{~cm}^{-1}\right)$. These results fit with the absence of crystalline minerals that was observed by XRD and petrographic microscopy, and allow identifying non-crystalline or poorly crystalline components. Some of them, such as Fe-oxides were previously observed by Vidal Romaní et al. (2010). 


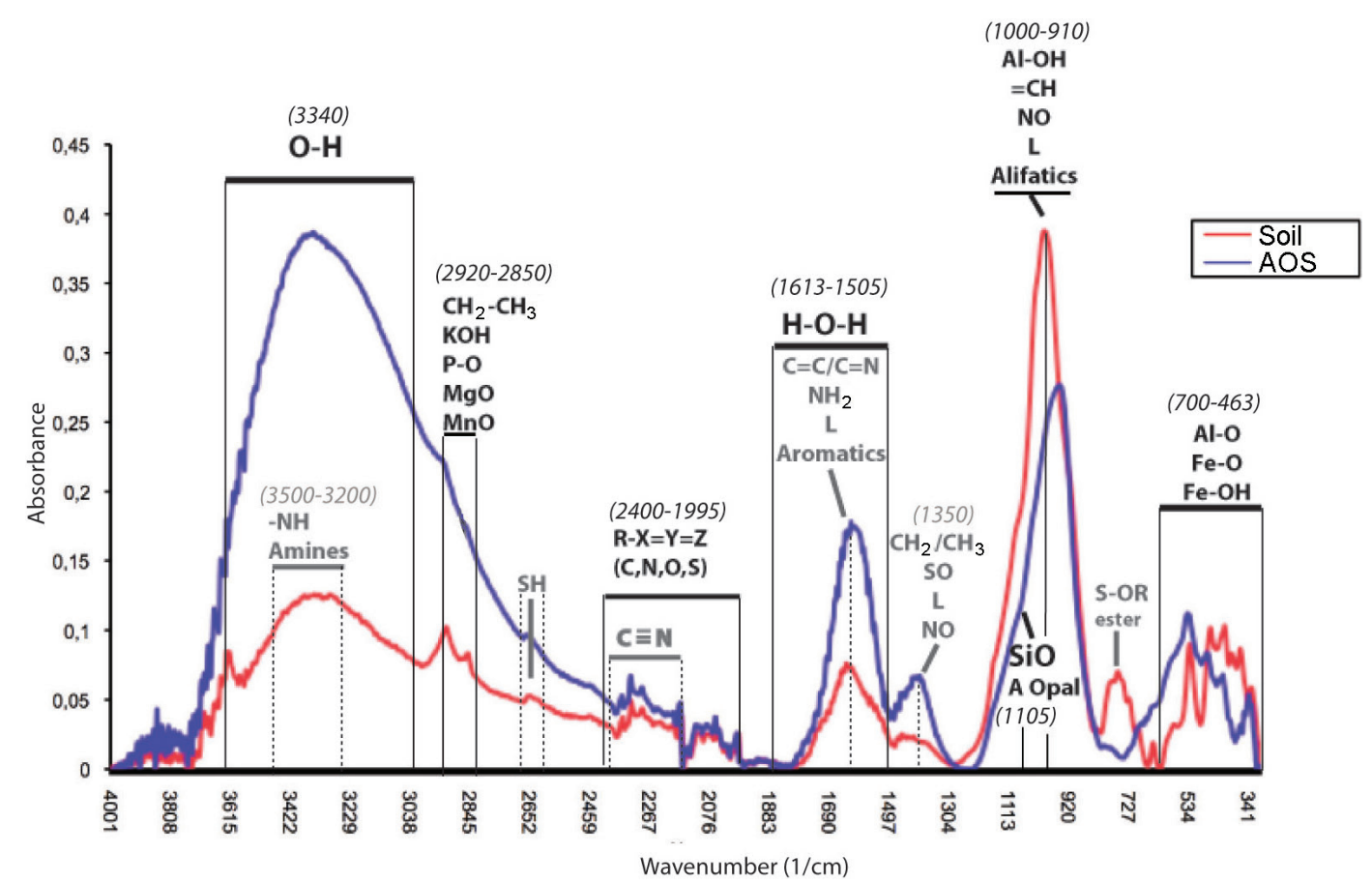

Fig. 6. FTIR spectra of a fine fraction of the bulk flowstone (blue line) and a sample of soil overlying the cave (red line). The identified bonds and their corresponding wavelength $\left(\mathrm{cm}^{-1}\right)$ are marked above each main peak.

Finally, TG-DTA did not provide additional information on the mineralogical composition of the samples. A bulk sample was analyzed and a mass loss of about $25 \%$ was observed (Fig. 7). Most of the mass loss occurs below $180^{\circ} \mathrm{C}$ (around $13 \%$ ) due to the (endothermic) dehydration reaction. An exothermic peak is observed round $350^{\circ} \mathrm{C}$ with a mass loss of about $11 \%$ between 240 and $500^{\circ} \mathrm{C}$, which can be attributed to the oxidation of organic matter. Above $600^{\circ} \mathrm{C}$, no mass loss was observed. Although some previous studies indicated the presence of aluminum oxides, opal, or gibbsite in similar speleothems (VidalRomaní et al., 2010; Filipi et al., 2020), no peaks corresponding to these phases were observed.

Evidence combined shows that the flowstone was mainly composed of poorly crystalline or amorphous phases (dominantly Al-oxides) that could have not been identified. Such observations fit the previously reported results by Vidal-Romani et al. (2010) and Filippi et al. (2020).

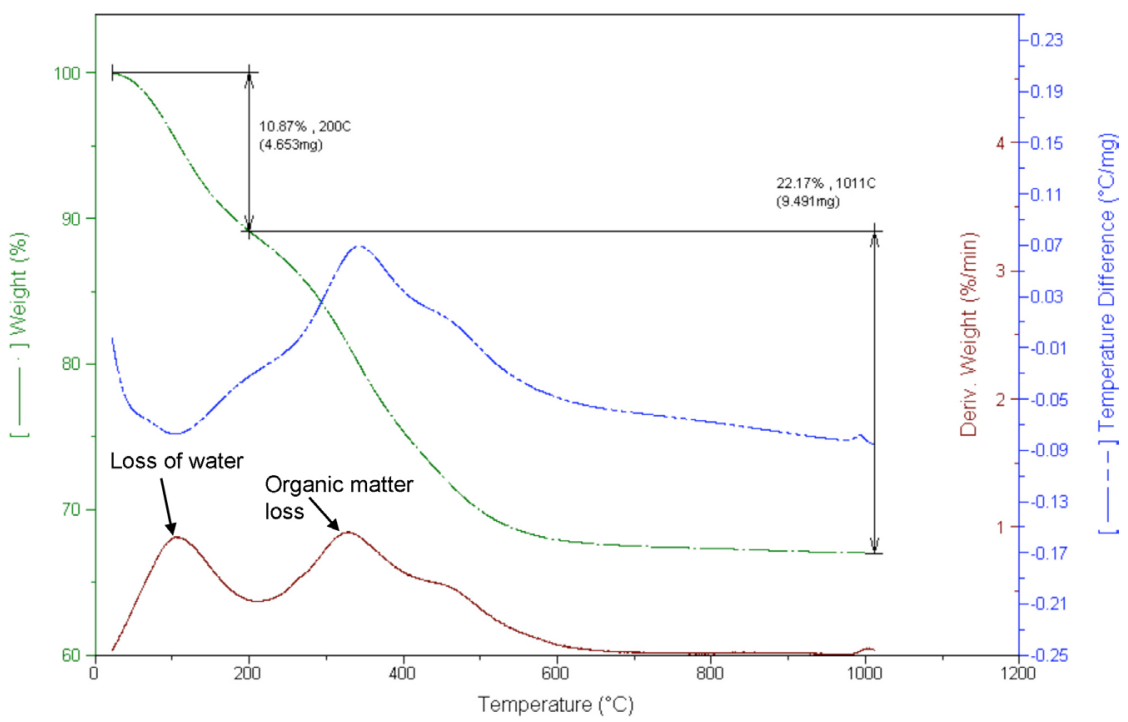

Fig. 7. TG-DTA plot of the bulk sample taken from the Al-rich speleothem. Loss of water and organic matter are observed.

\section{Chemical composition}

The bulk speleothem has a remarkably high Al content $\left(>60 \%\right.$ of $\mathrm{Al}_{2} \mathrm{O}_{3}$ ) and lower $\mathrm{Si}$ content $(<25 \%$ of $\mathrm{SiO}_{2}$ ). The values of $\mathrm{Si}$ and $\mathrm{Al}$ in the parent rock and soil overlying the cave are those expected in granite areas (Table 2). Due to such low $\mathrm{SiO}_{2} / \mathrm{Al}_{2} \mathrm{O}_{3}$ ratio $(<2.5)$, the speleothem has an allophane-like composition (Wada, 1980). Speleothems with similar constitution have been reported to originate from leaching of organic- rich soils overlying granite caves (Webb \& Finlayson, 1984; Parfitt, 2009; Filippi et al., 2020).

The speleothem is also enriched in $\mathrm{S}$ and $\mathrm{P}$, as well as in $\mathrm{Mn}$ and $\mathrm{Cl}^{-}$. Both $\mathrm{S}$ and $\mathrm{P}$ have previously been observed in allophane (Al-rich) speleothems (Ghergari \& Onac, 1993; Webb \& Finlayson, 1984). We suggest that they originate from the overlying soil environment. Mn is highly soluble and it can come from weathering of pyrolusite in granite. In addition, 
$\mathrm{Cl}^{-}$can also be associated with the sea spray. Contrary to the composition of bedrock and soil samples, the speleothem is depleted in $\mathrm{K}, \mathrm{Ca}, \mathrm{Na}, \mathrm{Mg}$, and Ti. Such elements are mostly present in silicate minerals such as feldspars, amphibole, pyroxene, and mica. They are scarcely observed within the speleothem layers as silty-sized grains. This explains their low content within the flowstone layers. Compared to previous studies, the elemental composition of the AOS is similar to those cited by Vidal-Romani et al. (2010) and Fillipi et al. (2020). However, Vidal Romani et al. (2010) reported $\mathrm{Al}_{2} \mathrm{O}_{3}$ concentrations around 30\% whereas our AOS shows $66.5 \%$. This is probably due to the fact that the authors considered a $50 \%$ of loss on ignition. Correcting these data, their estimated $\mathrm{Al}_{2} \mathrm{O}_{3}$ concentration would have been $\sim 60 \%$.

Table 2. Results of bulk XRF, Instrumental analyses (*) and Organic Carbon (OC) analyses $\left.{ }^{*}\right)$ of a soil sample overlying the cave and the studied speleothem.

\begin{tabular}{|c|c|c|c|}
\hline Oxides (\%) & Rock & Overlying soil & Studied speleothem \\
\hline $\mathrm{SiO}_{2}$ & 74.1 & 61.65 & 21.7 \\
\hline $\mathrm{Al}_{2} \mathrm{O}_{3}$ & 13.3 & 19.8 & 66.5 \\
\hline $\mathrm{K}_{2} \mathrm{O}$ & 7.5 & 7.2 & 0.18 \\
\hline $\mathrm{Na}_{2} \mathrm{O}$ & 2.5 & 5.25 & - \\
\hline $\mathrm{Fe}_{2} \mathrm{O}_{3}$ & 0.59 & 1.65 & 0.97 \\
\hline $\mathrm{CaO}$ & 0.40 & 1.35 & 0.076 \\
\hline $\mathrm{SO}_{3}$ & 0.33 & 1 & 2.6 \\
\hline $\mathrm{P}_{2} \mathrm{O}_{5}$ & 0.24 & 0.555 & 6.3 \\
\hline $\mathrm{MgO}$ & 0.19 & 0.43 & - \\
\hline $\mathrm{TiO}_{2}$ & 0.13 & 0.35 & 0.081 \\
\hline $\mathrm{MnO}$ & - & - & 0.12 \\
\hline $\mathrm{Cl}$ & - & 0.082 & 0.16 \\
\hline $\mathrm{Rb}_{2} \mathrm{O}$ & 0.051 & 0.06 & - \\
\hline $\mathrm{PbO}$ & & 0.044 & - \\
\hline $\mathrm{ZnO}$ & 0.010 & 0.028 & 0.019 \\
\hline $\mathrm{CuO}$ & 0.010 & 0.027 & 0.024 \\
\hline $\mathrm{SrO}$ & 0.007 & 0.007 & 0.066 \\
\hline $\mathrm{ZrO}_{2}$ & 0.011 & 0.011 & 0.011 \\
\hline $\mathrm{Br}$ & - & 0.008 & 0.32 \\
\hline $\mathrm{As}_{2} \mathrm{O}_{3}$ & - & - & 0.057 \\
\hline $\mathrm{Y}_{2} \mathrm{O}_{3}$ & - & - & 0.016 \\
\hline $\mathrm{N}^{*}$ & - & 1.012 & 0.402 \\
\hline $\mathrm{C}^{*}$ & - & 15.20 & 10.92 \\
\hline $\mathrm{H}^{*}$ & - & 1.84 & 4.54 \\
\hline $\mathrm{OC}^{*}$ & - & 14.86 & 10.51 \\
\hline
\end{tabular}

Despite the homogeneous composition observed in the bulk sample, if we consider our results and those of Vidal-Romani et al. (2010), the XRF analyses carried out in 30 different bands show a variability in the content of several oxides. In general, an inverse relationship between $\mathrm{Si}$ and $\mathrm{Al}$ content was observed. Also, a correlation in the contents of $\mathrm{Si}, \mathrm{Fe}, \mathrm{K}, \mathrm{Ti}$, and Mn exist (Fig. 8). This could be related to a higher detrital content in some layers, corresponding to feldspars and heavy minerals. However, these are not observed when individual bands were investigated by means of XRD and FTIR. An explanation for this is that the concentration of such minerals is very low, i.e. below detection limits. Such changes in the concentration of detrital grains in the bands could be related to minor changes in the flow of percolating water that in turn affects the transport mechanisms. During high flow rates, more detrital components could be carried and deposited into the flowstone, causing higher concentrations of $\mathrm{Si}, \mathrm{Fe}, \mathrm{K}$, and $\mathrm{Ti}$. Under drier conditions, less detrital grains are transported, and a decrease in such elements and a concomitant increase in Al (mostly transported in solution) would be observed. Hence, the observed chemical changes could serve as an environmental record, at least for the precipitation regime outside the cave. However, a more detailed chronology is needed for a detailed reconstruction, but this is beyond the scope of this work.

Water analyses show $\mathrm{pH}$ values around 6 with some differences between the water sampled upstream (5.93) and downstream (6.14) with respect to the speleothem. The concentrations of $\mathrm{NO}_{2}{ }^{-}$and $\mathrm{SO}_{2}{ }^{-}$are $1.66-1.07 \mathrm{mg} / \mathrm{L}$ and $1.13-1.18 \mathrm{mg} / \mathrm{L}$, respectively. The $\mathrm{Cl}^{-}$concentration is considerably lower below the speleothem $(7.95 \mathrm{mg} / \mathrm{L})$, compared with the $13 \mathrm{mg} / \mathrm{L}$ estimated in the above water sample (Table 3). $\mathrm{NO}_{3}^{-}$, $\mathrm{P}^{-}, \mathrm{Br}-$, and $\mathrm{F}^{-}$were below the detection limit $(<0.06$ $\mathrm{mg} / \mathrm{L})$. This is an interesting result, because although the concentration of $\mathrm{P}$ in the speleothem is high, it appears that is not precipitated from the dissolved $\mathrm{P}$. Regarding the C supply to the speleothem, in the water that drips out of the flowstone, the concentrations of total carbon (TC) and dissolved carbon (DC) is below the detection limit of $0.5 \mathrm{mg} / \mathrm{L}$, whereas in the water sample from the cave floor, values were higher $(0.62$ $\mathrm{mg}$ TC/L and $0.59 \mathrm{mg} \mathrm{DC} / \mathrm{L}$ ) (Table 3). This confirms that organic $\mathrm{C}$ from soil overlying the cave is poorly 


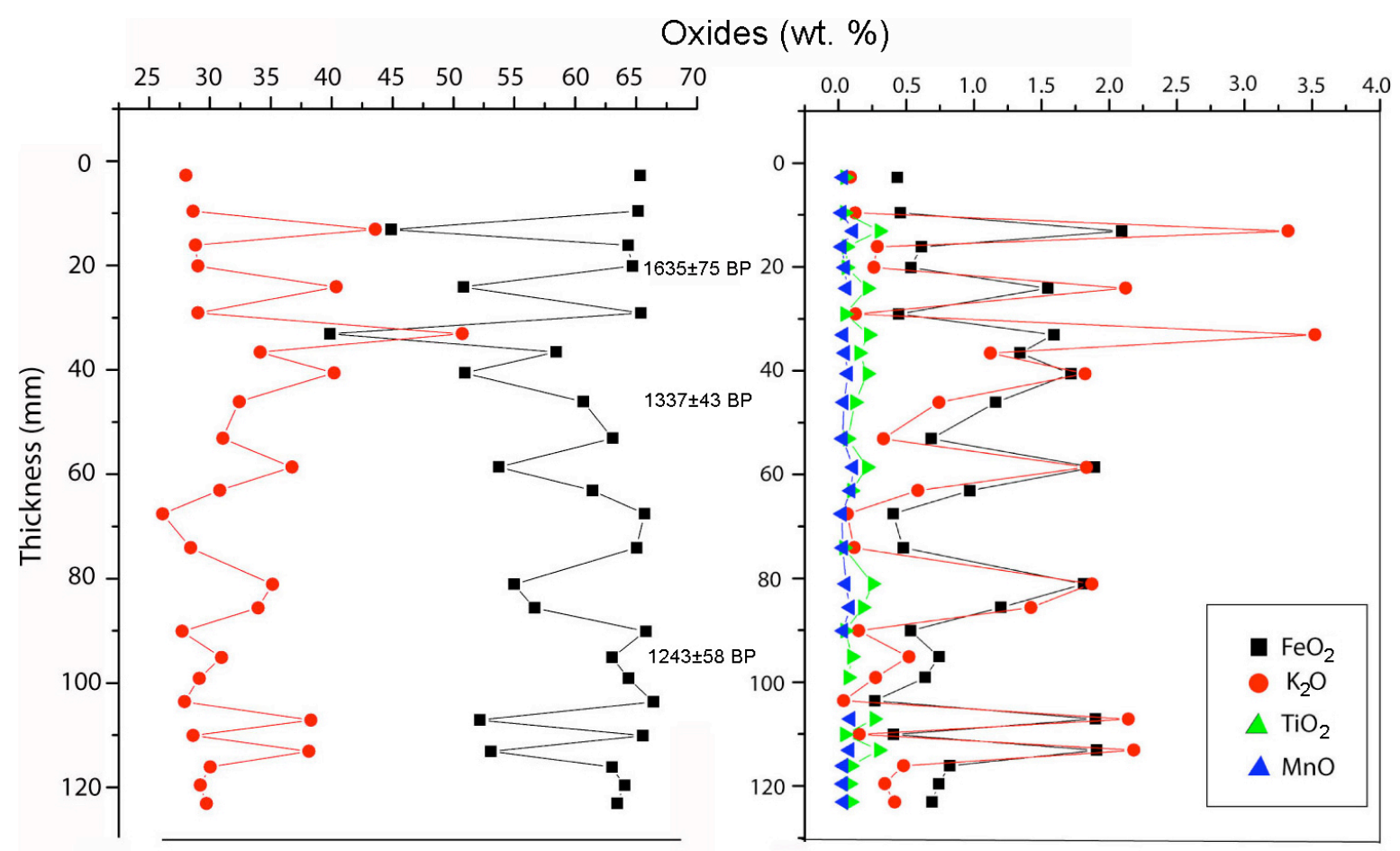

Fig. 8. Changes in the chemical composition of the speleothem as determined by XRF. The radiocarbon ages are also shown.

transported by infiltration water. Concentrations of dissolved metallic ions $\left(\mathrm{Mg}^{2+}, \mathrm{Al}^{3+}, \mathrm{Si}^{4+}\right.$, and $\left.\mathrm{Mn}^{2+}\right)$ are low $(0.3 \mathrm{mg} / \mathrm{L})$ and similar for both samples, and dissolved $\mathrm{Fe}^{3+}$ is below the detection limit $(<2 \mathrm{~g} / \mathrm{L})$. The concentrations of $\mathrm{Si}^{4+}$ and $\mathrm{Mg}^{2+}$ in the water exceed that of $\mathrm{Al}^{3+}$. The $\mathrm{Al}^{3+}$ concentration in the water below the studied speleothem is twice that of the water from the ceiling. Al is the main element present in the speleothem. This means that there is a mechanism that concentrates $\mathrm{Al}$ within the speleothem layers. If we consider the measured $\mathrm{pH}$ values of around 6 , the solubility of aluminum oxides and hydroxides is minimal, and would be higher at $\mathrm{pH}$ above and below this value (Thomas, 1994). The solubility of $\mathrm{Si}$ is minimal at $\mathrm{pH}$ values below 9, but higher than the solubility of aluminum oxides and hydroxides. This can explain the increase of $\mathrm{Al}$ with respect to $\mathrm{Si}$ in the speleothem. Other ions, such as $\mathrm{Ca}^{2+}, \mathrm{Mg}^{2+}, \mathrm{Fe}^{3+}$, $\mathrm{Na}^{+}$, and $\mathrm{Ti}^{4+}$ have also low solubility as oxides in aqueous solution of $\mathrm{pH}$ around 6 . This may be the cause of accumulation of $\mathrm{Al}$ oxides in the speleothem (Krauskopf, 1967). Note that both the water $\mathrm{pH}$ and composition are similar to that observed by Filippi et al. (2020) in the seepage inflow water in the granite Gobholo Cave (Eswatini, Africa), located in a humid subtropical climate.

Table 3. Results of analyses of ions and some elements present in the studied water samples.

\begin{tabular}{|c|c|c|}
\hline \multirow{3}{*}{ Component } & \multicolumn{2}{|c|}{ Sample/Location } \\
\hline & ATP-1 & ATP-2 \\
\hline & Above speleothem & Below speleothem \\
\hline $\mathrm{pH}\left(25^{\circ} \mathrm{C}\right)$ & 5.93 & 6.14 \\
\hline $\mathrm{F}^{-}(\mathrm{mg} / \mathrm{L})$ & $<0.06$ & $<0.06$ \\
\hline $\mathrm{Cl}^{-}(\mathrm{mg} / \mathrm{L})$ & 12.0 & 7.95 \\
\hline $\mathrm{NO}_{2}(\mathrm{mg} / \mathrm{L})$ & $<0.06$ & $<0.06$ \\
\hline $\mathrm{Br}^{-}(\mathrm{mg} / \mathrm{L})$ & $<0.06$ & $<0.06$ \\
\hline $\mathrm{NO}_{3}^{-}(\mathrm{mg} / \mathrm{L})$ & 1.66 & 4.07 \\
\hline $\mathrm{PO}_{4}{ }^{3-}(\mathrm{mg} / \mathrm{L})$ & $<0.15$ & $<0.15$ \\
\hline $\mathrm{P}^{3-}(\mathrm{mg} / \mathrm{L})$ & $<0.008$ & $<0.008$ \\
\hline $\mathrm{SO}_{4}{ }^{2-}(\mathrm{mg} / \mathrm{L})$ & 1.13 & 1.18 \\
\hline $\mathrm{NH}_{4}^{+}(\mathrm{mg} / \mathrm{L})$ & $<0.05$ & $<0.05$ \\
\hline $\mathrm{TC}(\mathrm{mg} / \mathrm{L})$ & 0.62 & $<0.50$ \\
\hline TOC (mg/L) & $<0.50$ & $<0.50$ \\
\hline $\mathrm{DC}(\mathrm{mg} / \mathrm{L})$ & 0.59 & $<0.50$ \\
\hline $\mathrm{DOC}(\mathrm{mg} / \mathrm{L})$ & $<0.50$ & $<0.50$ \\
\hline $\mathrm{Mg}^{2+}(\mathrm{mg} / \mathrm{L})$ & 0.30 & 0.29 \\
\hline $\mathrm{Al}^{3+}(\mathrm{mg} / \mathrm{L})$ & 0.092 & 0.183 \\
\hline $\mathrm{Si}^{4+}(\mathrm{mg} / \mathrm{L})$ & 1.7 & 1.7 \\
\hline $\mathrm{Mn}^{2}+(\mathrm{mg} / \mathrm{L})$ & 3.6 & 2.8 \\
\hline $\mathrm{Fe}^{3+}(\mu \mathrm{g} / \mathrm{L})$ & $<2.0$ & $<2.0$ \\
\hline
\end{tabular}




\section{Molecular composition of organic matter}

The C, N, S, and organic C (OC) contents of the overlying soil and the studied speleothem show that $\mathrm{OC}$ and $\mathrm{N}$ content are more abundant in the soil than in the speleothem (Table 2).

Figure 9 shows the total ion current chromatograms of the analyzed speleothem samples. The pyrolysis products were categorized according to chemical structure and tentative source in the following groups: monocyclic aromatic hydrocarbons (MAHs; benzene and alkylbenzenes), polycyclic aromatic hydrocarbons (PAHs; indenes, naphthalenes, biphenyl, acenapthylene, fluorene, phenanthrene, anthracene), carbohydrate products (cyclopentenones., furans, furfurals, 1,6-anhydrosugars, benzofurans), phenols, methylene chain compounds (MCC; n-alkanes, $n$-alkenes, $n$-alkanoic acids, n-alkylamides, $n$-alkylnitriles), other $\mathrm{N}$-containing compounds (pyrroles, pyridines, benzonitriles, indoles, acetamidofurans, diketopiperazines), lignin products (guaiacols and syringols), and "other" products (including unidentified ones), as shown in Table 4.

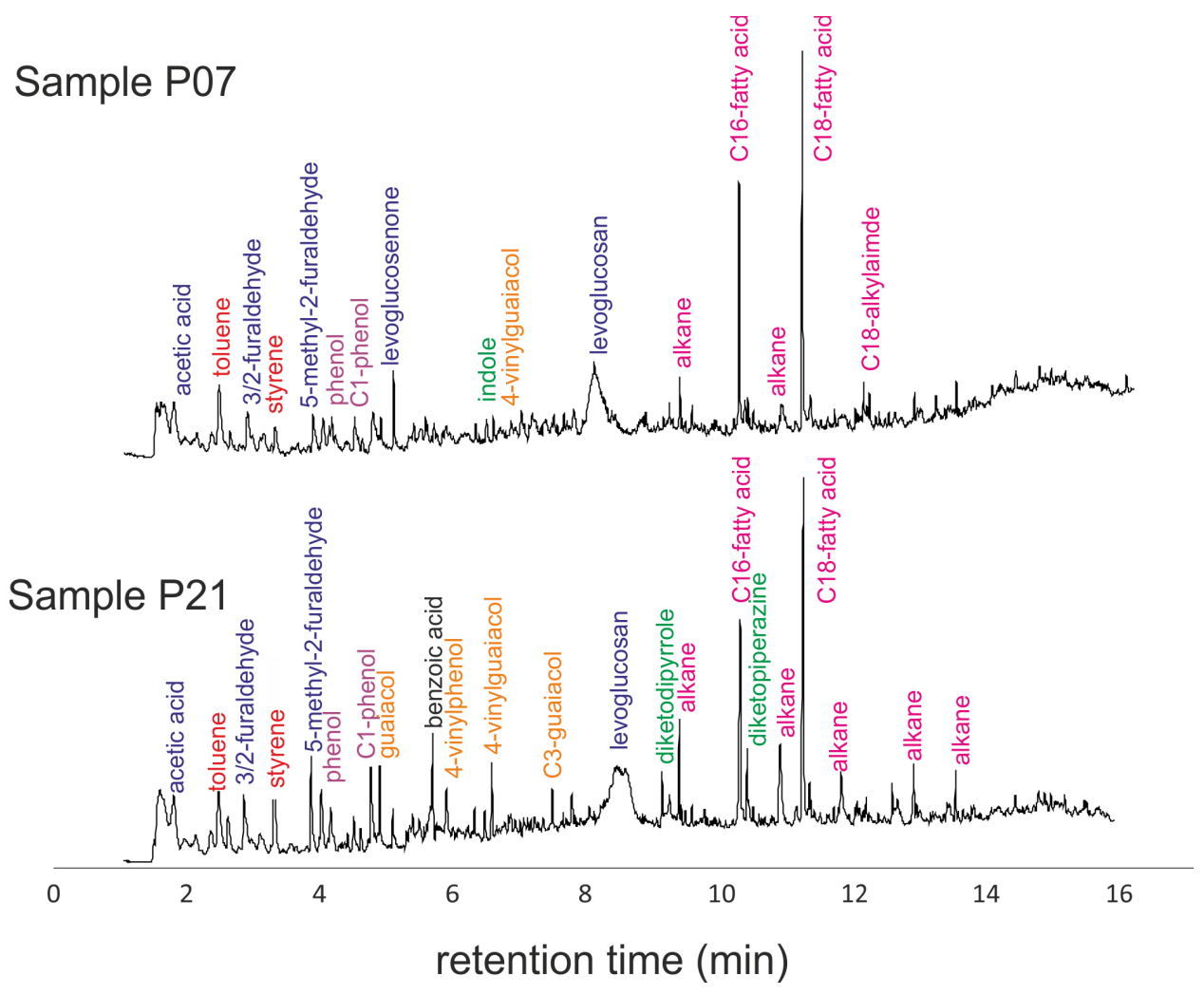

Fig. 9. Total ion current chromatograms obtained by Py-GC-MS of selected bands from the studied speleothem (after HF treatment). Pyrolysis product identifications of major peaks are indicated, with color schemes according to most likely source (blue: carbohydrates, red: monocyclic aromatic hydrocarbons, purple: phenols, orange: lignin, green: protein, pink: methylene chain compounds).

Table 4. Pyrolysis product categories (in bold font) and individual compounds, obtained from organic matter of the speleothem samples analyzed. $\mathrm{MCC}=$ methylene chain compounds, MAHs/PAHs = monocyclic/polycyclic aromatic hydrocarbons; RT = retention time, mass-to-charge ration $(\mathrm{m} / \mathrm{z})$ represents ion fragments used for semi-quantification.

\begin{tabular}{|l|c|c|c|c|}
\hline \multicolumn{1}{|c|}{ Pyrolysis product identification } & RT (min) & $\mathbf{m / z}$ & P07 & P21 \\
\hline Carbohydrate products & & $\sum$ & $\mathbf{3 4 . 4}$ & $\mathbf{3 7 . 5}$ \\
\hline Lignin products & & $\sum$ & $\mathbf{2 . 6}$ & $\mathbf{3 . 9}$ \\
\hline MCC & & $\sum$ & $\mathbf{1 4 . 7}$ & $\mathbf{1 1 . 2}$ \\
\hline MAHs & & $\sum$ & $\mathbf{1 5 . 1}$ & $\mathbf{1 6 . 2}$ \\
\hline N-containing products & & $\sum$ & $\mathbf{1 9 . 2}$ & $\mathbf{1 5 . 6}$ \\
\hline PAHs & & $\sum$ & $\mathbf{2 . 8}$ & $\mathbf{1 . 8}$ \\
\hline Phenols & & $\sum$ & $\mathbf{6 . 0}$ & $\mathbf{6 . 7}$ \\
\hline Other compounds & & $\sum$ & $\mathbf{5 . 3}$ & $\mathbf{7 . 2}$ \\
\hline Methyl-iodide & 1.693 & 142,127 & 1.9 & 1.4 \\
\hline C $_{1}$-cyclopentadiene & 2.060 & 79,80 & 0.6 & 0.4 \\
\hline C $_{2}$-cyclopentadiene & 2.420 & 79,94 & 1.2 & 1.0 \\
\hline Chlorocyclohexene & 2.981 & 81,116 & 0.0 & 0.0 \\
\hline Acetophenone & 4.749 & 105,77 & 0.7 & 0.7 \\
\hline Benzoic acid & 5.756 & 105,122 & 0.7 & 3.5 \\
\hline Unidentified compound & 7.535 & 124,166 & 0.1 & 0.0 \\
\hline tert-dibutylphenol & 7.833 & 191,206 & 0.2 & 0.2 \\
\hline C $_{1}$-tert-dibutylphenol & 7.924 & 205,220 & 0.0 & 0.0 \\
\hline
\end{tabular}


The pyrolyzate compositions of the two bulk samples (P07 and P21) are similar, with the carbohydrate products accounting for 34 and $38 \%$ of the total quantified peak area (TQPA), respectively. Levoglucosan is the most abundant, followed by several furans, furaldehydes, and pyranones (Pouwels et al., 1989). The methoxyphenols (guaiacols) and dimethoxyphenols (syringols) accounted for 2.6-3.9\% of TQPA in the bulk samples. These compounds are markers of vascular plant-derived organic matter. Guaiacols predominate over syringols, and 4-vinylguaiacol is particularly abundant. This suggests that the methoxyphenols originate from a combination of lignin and lignin-like phenolic acids, the latter of which are abundant in herbaceous vegetation (Ralph \& Hatfield, 1991). The MCC account for $11-14 \%$ and are dominated by $n$-alkanoic acids and homologous series of $n$-alkanes and $n$-alkenes. These compounds may originate from many aliphatic precursors, such as free fatty acids, waxes, suberin and cutin (Nierop, 1998). Nitrogen-containing compounds account for $15-19 \%$. The origin of this set of compounds is diverse: (1) acetamide and acetamidofurans originate from the chitin in fungal cell walls or perhaps guano of insectivorous animals (Stankiewicz et al., 1996), (2) cyanobenzenes and diketopiperazines are primarily protein products (Tsuge \& Matsubara, 1985), (3) $n$-alkylamides and $n$-alkylnitriles may be secondary rearrangements between inorganic $\mathrm{N}$ and $n$-alkanoic acids or occur as such (Nierop \& Van Bergen, 2002), (4) benzonitriles may originate from protein and pyrogenic material (Kaal et al., 2008), and (5) other products such as pyrroles, pyridines and indoles are not specific of a given precursor. The presence of chitin ( $N$-acetyl-glucosamine polymer) markers, and high proportion of $\mathrm{N}$-containing pyrolysis products in general, are strong indications that microbial and/or arthropod tissues form a major fraction of the organic matter. They also indicate that a large proportion of the carbohydrate markers, especially the furans and furaldehydes (Stankiewicz et al., 1996), but potentially levoglucosan as well (Vancampenhout et al., 2008), originate from chitins. The MAHs account for $15-16 \%$, the vast majority of which corresponds to toluene. The abundance of $\mathrm{N}$-containing products, suggests that toluene originates mainly from (possible chitin-entangled) proteinaceous material (Tsuge \& Matsubara, 1985). PAHs account for 1.8-2.8\%. They may originate from Black C (pyrogenic material, for instance charcoal residues) (Ross et al., 2005), but matrix effects cannot be ruled out (Miltner \& Zech, 1997) and the abundance of $\mathrm{C}_{2}$ - and $\mathrm{C}_{3}$-indenes and -naphthalenes suggest that resin-like components can be a significant alternative source of the PAHs (González-Pérez et al., 2014; Kaal et al., 2019). Phenols account for 6.0-6.7\%. Similar to the MAHs, these phenols are undiagnostic compounds, which in this case might primarily correspond to proteinand lignin-derivatives. Among the "other" compounds benzoic acid is the most abundant, especially in sample BU-21, but its source is unknown.

In conclusion, Py-GC-MS showed that the speleothem organic matter is comprised, in decreasing order of (1) microbial tissue (carbohydrates, chitin, and proteins), (2) plant-derived polyphenols (lignin) and polysaccharides, (3) aliphatic and possibly some (4) resinous material from an unknown source, and (5) pyrogenic matter (Table 5). These results are in agreement with the carbon analyses of the overlying soil sample, the speleothem, and water samples. There are no signs of significant transport of dissolved organic matter in the infiltrating water. The phenolic compound distribution (4-vinylphenol, 4-vinylguaiacol and propenylguaiacol) is not consistent with that of dissolved organic matter (phenol, phenols and simpler guaiacols) (Kaal et al., 2017), which implies that infiltrating water from above the cave is an unlikely source of the lignin (Kaal et al., 2017). Hence, the detection of vascular plant-derived compounds (lignin) is an unambiguous evidence of the presence of traces of exogenous organic matter, but likely not transported into the cave as dissolved but as suspended/colloidal matter. It has also been suggested earlier that the microbial biomass is the main component of the organic matter in speleothems of granite caves (Vidal Romaní et al., 2015).

\section{Age and growth rates}

Three out of the 30 separated bands of the speleothem sequence were dated by radiocarbon analysis. Samples P7, P13, and P22 (Fig. 3) encompass $7.5 \mathrm{~cm}$ of the flowstone's total thickness $(12.31 \mathrm{~cm})$ and define a growth period of $\sim 392 \pm 133 \mathrm{yr}$ (Table 5). As the thickness of the laminae that form the bands ranges from 17 to $33 \mathrm{~mm}$, it can be inferred that the number of laminae in the $7.5 \mathrm{~cm}$ thick section of the speleothem is around $\sim 3,342 \pm 107$. This corresponds to the formation of approximately 8-9 laminae/year, and a growth rate of $0.191 \pm 0.065 \mathrm{~mm} / \mathrm{yr}$, assuming a continuous accretion model. Thus, the observed laminae (rhythms) do not correspond to seasonal but to continuous changes in the percolating water flow. The climate of the area is humid, with a short summer dry period and rainfall present most of the year, without strong seasonality and high yearly precipitation (around 2,000 mm/yr). As the thickness of the bands range from 0.5 to $1.0 \mathrm{~cm}$, they should be formed in a period of approximately 40 to 100 years.

It can be concluded that the speleothem was formed during Late Holocene. Radiocarbon ages of 1,500 to 3,000 years BP were obtained from similar flowstones (Vidal-Romani et al., 2010), the latter age of which corresponds to a different AOS from A Trapa Cave System.

There are abundant recent environmental records from studied continental deposits that correspond to this period in NW Spain. These can be used to cross-check the geochemical data derived from the flowstone, and thereby to assess the potential of such Al-rich speleothems as environmental archives. The growth period of the studied flowstone spans from the late Roman Period to the Dark Ages, also referred as Late Antique Little Ice Age, a period that is characterized by a cool and dry climate compared to the previous Roman Period and later Middle Ages 
Table $5 .{ }^{14} \mathrm{C}$ AMS radiocarbon and calibrated ages.

\begin{tabular}{|l|c|c|c|c|}
\hline \multicolumn{1}{|c|}{ Sampled band } & Distance from bottom (cm) & Lab code & Uncal. age (yr BP) & Cal. age (yr BP) \\
\hline P7 & 2.01 & Beta-378982 & $1730 \pm 30$ & $1635 \pm 75$ \\
\hline P13 & 4.61 & Beta-381222 & $1440 \pm 30$ & $1337 \pm 43$ \\
\hline P22 & 9.51 & Beta-381223 & $1330 \pm 30$ & $1243 \pm 58$ \\
\hline
\end{tabular}

Optimum (PAGES 2k Consortium, 2013; Büntgen et al., 2016). Continental records from the same region obtained from carbonate stalagmite analysis (Railsback et al., 2011, 2017) and oceanic cores (Bernárdez et al., 2008) reflect such cold and dry period in the area and Western Europe (Büntgen et al., 2016). A more detailed age-depth model of the flowstone could potentially provide a more precise record of changes in rainfall in the area. However, such a refined age model is not available at this time.

A particular question is the reason why the growth of the speleothem ceased. One possible reason is the lack of space for growth, as the speleothem precipitated in a joint between two granite blocks. There is not evidence of the possible causes, but the space limitation appear to be a reliable hypothesis.

The obtained age of the studied speleothem also raises a question whether the radiocarbon dating of the organic matter provides reliable ages. The Py-GC-MS data showed that most of the organic matter corresponds to microbial tissue with minor proportions of plant-derived polyphenols (lignin) and, aliphatic and resinous material from (an) unknown source(s). It seems obvious that the vascular plantderived organic matter corresponds to detritus that formed before transport into the cave (from plant to soil to the cave by percolating water fluxes), and then deposited in the speleothem, allowing to radiocarbon date the time when certain layers formed. If the microbial content of the speleothem originates in the soil, we can assume that its radiocarbon activity would not bias the overall ${ }^{14} \mathrm{C}$ age of the speleothem. However, if the microorganisms are active within the speleothem matrix, they will incorporate new $\mathrm{C}$ (and new ${ }^{14} \mathrm{C}$ ) to the speleothem. This would cause an underestimation of the resulting ${ }^{14} \mathrm{C}$ age. The pyrogenic organic matter, which is also derived from the outside of the cave, is known to persist in soil for many years due to its refractory nature, which may therefore be a source of "over-aged" C (Ferro-Vázquez et al., 2019), but its effects on average ${ }^{14} \mathrm{C}$ activity are expected to be small due to its minor contribution, if any. More detailed assessment of the organic matter is needed to better understand the transformations of organic matter within the speleothem. Alternatively, optically stimulated luminescence dating can be employed on the observed detrital quartz and feldspars grains which originate from above the cave in order to determine the chronology (Sanjurjo-Sánchez \& Vidal Romani, 2011).

\section{CONCLUSIONS}

The analyses of an Al-bearing organic-rich speleothem of the A Trapa Cave System revealed that the sources of these speleothems, which are often found in granite caves, are related predominantly to materials (dissolved ions, detrital mineral grains, and organic matter) that are transported by infiltration water from the soil covering the cave. However, they may be influenced by the activity of organisms living in the speleothem and probably also transported by the percolating water.

Slow water infiltration transports some dissolved ions (from weathered silicate minerals), detrital mineral grains and organic matter from the soil above the cave to form these speleothems by layer accretion, which are preserved under high relative humidity conditions. The accretion of laminae is possibly related to changes in the flow conditions of the percolation water, which are controlled by changes in rainfall and soil moisture. Thus, the layers have the potential to provide information on past environmental changes.

The molecular features of the organic matter found within the flowstone allowed to unambiguously identify exogenous sources (plant-derived lignin), in addition to microbial organic matter which may come from the soil environment or the speleothem environment (in situ production).

The radiocarbon ages obtained for the speleothem reveal a fast growth rate. The time span of the speleothem formation is approximately $\sim 392 \pm 133 \mathrm{yr}$. The estimated growth rate is around $0.191 \pm 0.065$ $\mathrm{mm} / \mathrm{yr}$, which corresponds to ca. 8-9 laminae per year. Such laminae are grouped in bands that represent timeframes of 40-100 years. This reveals that theoretically they could be used as high resolution records of environmental change. However, a higher resolution and more precise chronology is needed before such studies can be successfully completed. In summary, this study adds new information on the structure, composition, and growth of Al-rich speleothem in granite caves, and discusses ways future research can help better understanding these under studied speleothems.

\section{ACKNOWLEDGEMENTS}

This research has been funded projects CGL201130141 of the Ministry of Education and Science of Spain. Moreover, support from Xunta de Galicia has been received towards the programs "Proxectos para Investigadores Emerxentes" (EM2013/056). "Consolidación y estructuración de unidades de investigación competitivas: Grupos de potencial de crecimiento" (ED431B 2018/47) and "Redes de investigación" (ED431D 2017/08). The authors would like to thank Dr. Roman Aubrecht and two anonymous reviewers for their careful review and valuable suggestions and comments.

Authorship Statement: JSS and JRVR designed and directed the study, CAR performed most chemical analyses and VBR some mineralogical analyses. 
MVR performed the cave environmental study and model and JK studied the organic matter. All authors participated in the writing and revision of the manuscript, led by JSS.

\section{REFERENCES}

Aubrecht, R., Brewer-Carias, Ch., Smida, B., Audy, M., Kovacik, L., 2008. Anatomy of biologically mediated opal speleothems in the World's largest sandstone cave: Cueva Charles Brewer. Chimantá Plateau. Venezuela. Sedimentary Geology, 203, 181-195. https://doi.org/10.1016/j.sedgeo.2007.10.005

Badino, G., 2004. Cave temperatures and global climatic change. International Journal of Speleology, 33, 103113. https://doi.org/10.5038/1827-806X.33.1.10

Bernárdez, P., González-Álvarez, R., Francés, G., Prego, R., Bárcena, M.A., Romero, O.E., 2008. Late Holocene history of the rainfall in the NW Iberian peninsula Evidence from a marine record. Journal of Marine Systems, 72, 366-382.

https://doi.org/10.1016/j.jmarsys.2007.03.009

Bronk Ramsey, C., Lee, S., 2013. Recent and planned developments of the program OxCal. Radiocarbon, 55(2-3), 720-730.

https://doi.org/10.1017/S0033822200057878

Brunet, M., Saladi, O., Jones, P., Sigro, J., Aguilar, E., Moberg, A., Lister, D., Walther, A., Lopez, D., Almarza, C., 2006. The development of a new dataset of Spanish daily adjusted temperature series (SDATS) (18502003). International Journal of Climatology, 26, 1777 1802. https://doi.org/10.1002/joc. 1338

Büntgen, U., Myglan, V.S., Ljungqvist, F.C., McCornick, M., Di Cosmo, N., Sigl, M., Jungclaus, J., Wagner, S., Krusic, P.J., Esper, J., Kaplan, J.O., de Vaan, M.A.C., Luterbacher, J., Wacker, L., Tegel, W., Kirdyanov, A.V., 2016. Cooling and societal change during the Late Antique Little Ice Age from 536 to 660 AD. Nature Geoscience, 9, 231-236.

https://doi.org/10.1038/ngeo2652

Chabert, C., Courbon, J., 1997. Atlas des cavités non calcaires du monde. Ed. Pré de Madame Carle, Paris, 109 p.

Fairchild, I.J. \& Baker, A., 2012 - Speleothem science: From process to past environments. John Wiley \& Sons, Chichester, $416 \mathrm{p}$. https://doi.org/10.1002/9781444361094

Ferro-Vázquez, C., Kaal, J., Santos Arévalo, F.J., Criado, F., 2019. Molecular fingerprinting of $14 \mathrm{C}$ dated soil organic matter fractions from archaeological settings in NW Spain. Radiocarbon, 61, 101-130. https://doi.org/10.1017/RDC.2018.62

Filippi, M., Bruthans, J., Skála, R., Mészárosová, N., 2020. Speleothems of the granite Gobholo Cave in Eswatini. Journal of African Earth Sciences, 172, 103986. https://doi.org/10.1016/j.jafrearsci.2020.103986

Ghergari, L., Onac, B.P., 1993. Crisite - a new mineral species found in the Bolhac Cave (Padurea Craiului Mountans, Romania). Bulletin Société Géographique Liège, 29, 97-104.

González López, L., 2018. Cavidades desarrolladas en rocas magmáticas: troglobios y alteración de la roca. Aplicaciones a la vida extraterrestre. Unpublished $\mathrm{PhD}$ Thesis, University of A Coruña, $327 \mathrm{p}$.

González-Pérez, J.A., Almendros, G., de la Rosa, J.M., González-Vila, F.J., 2014. Appraisal of polycyclic aromatic hydrocarbons (PAHs) in environmental matrices by analytical pyrolysis (Py-GC/MS). Journal of Analytical and Applied Pyrolysis, 109, 1-8.

https://doi.org/10.1016/j.jaap.2014.07.005
González-Pimentel, J.L., Miller, A.Z., Jurado, V., Laiz. L., Pereira, M.F.C., Saiz-Jimenez, C., 2018. Yellow coloured mats form lava tubes of La Palma (Canary Islands, Spain) are dominated by metabolically active Actinobacteria. Scientific Reports, 8, 1944-1955. https://doi.org/10.1038/s41598-018-20393-2

Gustafson, G., Krásny, J., 1993. Crystalline rock aquifers: their occurrence. Use and importance. Memories I.A.H. XXIV (Part. 1). 24th Congress of International Association of Hydrogeologists, Oslo, p. 3-20.

Hill, C.A., Forti, P., 1995. The classification of cave minerals and speleothems. International Journal of Speleology, 24, 77-82. https://doi.org/10.5038/1827-806X.24.1.5

IGME, 1971. Mapa geologico de Espana 1:200.000 Sintesis de la cartografia existente Pontevedra-La Guardia: Primera edicion, Instituto Geologico y Minero de Espana, 29 p.

Johnston, J.F.W., 1840. On the constitution of Pigotite and on the Mudesous and Mudesic acids. Philosophical Transactions of the Royal Society of London, 4, 18371843. https://doi.org/10.1098/rspl.1837.0126

Kaal, J. Martínez-Cortizas, A., Biester, H., 2017. Downstream changes in molecular composition of DOM along a headwater stream in the Harz mountains (Central Germany) as determined by FTIR, PyrolysisGC-MS and THM-GC-MS. Journal of Analytical and Applied Pyrolysis, 126, 50-61. https://doi.org/10.1016/j.jaap.2017.06.025

Kaal, J., Linderholm, J., Martínez Cortizas, A., 2019. Fire, meat and totarol: organic matter in the embankments of the Neolithic site Bastuloken (North Sweden). Analytical Pyrolysis Letters, APL007, 1-16. https://pyrolyscience.com/ap1007/

Kašing, M., Lenart, J., 2020. Cave airflow mechanism of a crevice-type cave: A case study from Czechia. International Journal of Speleology, 49(1), 55-67. https://doi.org/10.5038/1827-806X.49.1.2285

Krauskopf, K.B., 1967. Introduction to geochemistry. McGraw-Hill, New York, 721 p.

Lagarde, J.L., Capdevila, R., Fourcad, E., 1992. Granites et colision continentale: 1 example des granitoides carboniferes dans la chaine hercynienne ouesteuropéenne. Bulletin Societe Géologie France, 163, 597-610.

Lavoie, K., Witer, A.S., Read, K.J.H., Hughes, E.M., Spilde, M.N., Northup, D.E., 2017. Comparison of bacterial communities from lava cave microbial mats to overlying surface soils from Lava Beds National Monument, USA. PlosOne, 12(2), e0169339. https://doi.org/10.1371/journal.pone.0169339

Miltner, A., Zech. W., 1997. Effects of minerals on the transformation of organic matter during simulated fire-induced pyrolysis. Organic Geochemistry, 26, 175182. https://doi.org/10.1016/S0146-6380(97)00002-8

Nierop, K.G.J., 1998. Origin of aliphatic compounds in a forest soil. Organic Geochemistry, 29, 1009-1016. https://doi.org/10.1016/S0146-6380(98)00165-X

Nierop, K.G.J., van Bergen P.F., 2002. Clay and ammonium catalyzed reactions of alkanols. alkanoic acids and esters under flash pyrolytic conditions. Journal of Analytical and Applied Pyrolysis, 63, 197208. https://doi.org/10.1016/S0165-2370(01)00154-1

Nieuwenhuize, J., Maas, Y.E.M., Middelburg, J.J., 1994. Rapid analysis of organic carbon and nitrogen in particulate materials. Marine Chemistry, 45, 217-224. https://doi.org/10.1016/0304-4203(94)90005-1

PAGES 2k Consortium, 2013. Continental-scale temperature variability during the past two millennia. Nature Geoscience, 6, 339-346. https://doi.org/10.1038/ngeo1797 
Parfitt, R.L., 2009. Allophane and imogolite: role in soil biogeochemical processes. Clay Minerals, 44, 135-155. https://doi.org/10.1180/claymin.2009.044.1.135

Pouwels, A.D., Eijkel G.B., Boon, J.J., 1989. Curiepoint pyrolysis-capillary gas chromatography-highresolution mass spectrometry of microcrystalline cellulose. Journal of Analytical and Applied Pyrolysis, 14, 237-280. https://doi.org/10.1016/0165-2370(89)80003-8

Principe, J.C., Euliano, N.R., Lefebvre W.C., 2000. Neural and adaptive systems: Fundamentals through simulations. Wiley, New York, 672 p.

Railsback, L.B., Liang, F., Vidal-Romaní, J.R., Grandald'Anglade, A., Vaqueiro-Rodríguez, M., Santos-Fidalgo, L., Fernández-Mosquera, D., Cheng, H., Edwards, R.L., 2011. Petrographic and isotopic evidence for Holocene long-term climate change and shorter-term environmental shifts from a stalagmite from the Serra do Courel of northwestern Spain, and implications for climatic history across Europe and the Mediterranean. Palaeogeography, Palaeoclimatology, Palaeoecology, 305, 172-184.

https://doi.org/10.1016/j.palaeo.2011.02.030

Railsback, L.B., Liang, F., Vidal-Romaní, J.R., Garrett, K.B., Sellers, R., Vaqueiro-Rodríguez, M., Grandald'Anglade, A., Cheng, H., Edwards, R.L., 2017. Radiometric, isotopic, and petrographic evidence of changing interglacials over the past 550,000 years from six stalagmites from the Serra do Courel in the Cordillera Cantábrica of northwestern Spain. Palaeogeography, Palaeoclimatology, Palaeoecology, 466, 137-152.

https://doi.org/10.1016/j.palaeo.2016.11.020

Ralph, J., Hatfield, R.D., 1991. Pyrolysis-GC-MS characterization of forage materials. Journal of Agricultural Food Chemistry, 39, 1426-1437. https://doi.org/10.1021/jf00008a014

Reimer, P.J., Bard, E., Bayliss, A., Beck, J.W., Blackwell, P.G., Bronk Ramsey, C., Grootes, P.M., Guilderson, T.P., Haflidason, H., Hajdas, I., Hatté, C., Heaton, T.J., Hoffmann, D.L., Hogg, A.G., Hughen, K.A., Kaiser, K.F., Kromer, B., Manning, S.W., Niu, M., Reimer, R.W., Richards, D.A., Scott, E.M., Southon, J.R., Staff, R.A., Turney, C.M., van der Plicht, J., 2013. IntCal13 and Marine 13 radiocarbon age calibration curves 0-50,000 years cal BP. Radiocarbon, 55, 1869-1887.

https://doi.org/10.2458/azu_js_rc.55.16947

Riquelme, C., Rigal, F., Hathaway, J.J.M., Northup, D.E., Spilde, M.N., Borges, P.A.V., Gabriel, R., Amorim, I.R., Dapkevicius, M.L.N.E., 2015. Cave microbial community composition in oceanic islands: Disentangling the effect of different colored mats in diversity patterns of Azorean lava caves. FEMS Microbiology Ecology, 91, fiv141.

https://doi.org/10.1093/femsec/fiv141

Ross, A., Junyapoon, S., Jones, J.M., Williams, A., Bartle, K.D., 2005. A study of different soots using pyrolysisGC/MS and comparison with solvent extractable material. Journal of Analytical and Applied Pyrolysis, 74, 494-501.

https://doi.org/10.1016/j.jaap.2004.11.011

Sanjurjo-Sánhez, J., Vidal Romaní, J.R., Vaqueiro, M., Costas Vázquez, R. Grandal d'Anglade, A., 2013. TL estimation of ages of pottery fragments recovered from granite aves in the NW coast of Spain. Cadernos do Laboratorio Xeolóxico de Laxe, 37, 73-88.

Sanjurjo-Sánchez, J., Vidal Romaní, J.R., 2011. Luminescence dating of pseudokarst speleothems: A first approach. Spectroscopy Letters, 44, 543-548. https://doi.org/10.1080/00387010.2011.610422
Sauro, F., Cappelletti, M., Ghezzi, D., Columbu, A., Hong, P.-Y., Zowawi, H.M., Crabone, C., Piccini, L., Vergara, F., Zannoni, D., De Waele, J., 2018. Microbial diversity and biosignatures of amorphous silica deposits in orthoquartzite caves. Scientific Reports, 8, 1756917569. https://doi.org/10.1038/s41598-018-35532-y

Stankiewicz, B.A., van Bergen, P.F., Duncan, I.J., Carter, J.F., Briggs, D.E.G., Evershed, R.P., 1996. Recognition of chitin and proteins in invertebrate cuticles using analytical pyrolysis/gas chromatography and pyrolysis/gas chromatography/mass spectrometry. Rapid Communications in Mass Spectrometry, 10, 1747-1757.

https://doi.org/10.1002/(SICI)1097-0231(199611) 10:14\%3C1747::AID-RCM713\%3E3.0.CO;2-H

Thomas, M.F., 1994. Geomorphology in the tropics. A study of weathering and denudation in low latitudes, John Wiley \& Sons, Chichester, 460 p.

Tsuge, S., Matsubara, H., 1985. High-resolution pyrolysis-gas chromatography of proteins and related materials. Journal of Analytical and Applied Pyrolysis, 8, 49-64.

https://doi.org/10.1016/0165-2370(85)80014-0

Twidale, C.R., Vidal Romaní, J.R., 2005. Landforms and geology of granite terrains. Balkema, London, 351 p. https://doi.org/10.1201/9781439833704

Vaqueiro-Rodríguez, M., Costas-Suárez, R., VidalRomani, J.R., 2015. Geomorphological mapping of the sismotectonic cave system of A Trapa, Ribadelouro, Tui (Galicia, Spain). International Union of Speleology, Pseudokarst Commission Newsletter, 25, 34-42.

Vancampenhout, K., Wouters, K., Caus, A., Buurman, P., Swennen, R., Deckers, J., 2008. Fingerprinting of soil organic matter as a proxy for assessing climate and vegetation changes in last interglacial palaeosols (Veldwezelt. Belgium). Quaternary Research, 69, 145162. https://doi.org/10.1016/j.yqres.2007.09.003

Vieten, R., Winter, A., Warken, S.F., Schröder-Ritzrau, A., Miller, T.E., Scholz, D., 2016. Seasonal temperature variations controlling cave ventilation processes in Cueva Larga, Puerto Rico. International Journal of Speleology, 45(3), 259-273.

https://doi.org/10.5038/1827-806X.45.3.1983

Vidal Romaní, J.R., 1989. Geomorfologia granitica en Galicia (NW Espana). Cuadernos Laboratorio Xeolóxico de Laxe 13, 89-163.

Vidal Romaní, J.R., Vaqueiro, M., 2007. Types of granite cavitites and associated speleothems: Genesis and evolution. Nature Conservation, 63, 41-46.

Vidal Romaní, J.R., Vaqueiro, M., Sanjurjo, J., 2014. Granite landforms in Galicia. In: Gutierrez, M., Gutierrez, M. (Eds.) Landscapes and landforms of Spain. Springer, Dordrecht, p. 63-39. https://doi.org/10.1007/978-94-017-8628-7 4

Vidal Romaní, J.R., Twidale, C.R., Bourne, J., Campbell, E.M., 1998. Espeleotemas y formas constructivas en granitoides. In: Ortiz, A.G., Franch, F.S. (Eds.), Investigaciones recientes en la Geomorfología española. Actas Reunión de Geomorfología (Granada), Barcelona, p. 777-782.

Vidal Romaní, J.R., Bourne, J.A., Twidale, C.R., Campbell, E.M., 2003. Siliceous cylindrical speleothems in granitoids in warm semiarid and humid climates. Zeitschrift für Geomorphologie, 47, 417-437.

Vidal Romaní, J.R., González López, L., Vaqueiro, M., Sanjurjo-Sánchez, J., 2015. Bioweathering related to groundwater circulation in cavities of magmatic rock massifs. Environmental Earth Sciences, 73, 29973010. https://doi.org/10.1007/s12665-014-3743-2 
Vidal Romaní, J.R., Sanjurjo, J., Vaquerio, M., Fernández Mosquera, D., 2010. Speleothem development and biological activity in granite cavities. Geomorphologie: relief, processus, environnement, 4, 337-346.

https://doi.org/10.4000/geomorphologie.8055

Wada, K., 1980. Mineralogical characteristics of andisols. In: Teng, B.K.G. (Ed.), Soils with variable charge. New Zealand Society of Soil Science, Lower Hutt, p. 87-107.

Webb, J.A., Finlayson, B.L., 1984. Allophane and opal speleothems from granite caves in south-east Queensland. Australian Journal of Earth Sciences, 31, 341-349.

https://doi.org/10.1080/14400958408527935
Zegouagh, Y., Derenne, S., Dignac, M.-F., Baruiso, E., Mariotti, A., Largeau, C., 2004. Demineralisation of a crop soil by mild hydrofluoric acid treatment. Influence on organic matter composition and pyrolysis. Journal of Analytical and Applied Pyrolysis, 71, 119-135. https://doi.org/10.1016/S0165-2370(03)00059-7

Zhang, X., Sanderson, D.J., Barker, A.J., 2002. Numerical study of fluid flow of deforming fractured rock using dual permeability model. Geophysical Journal International, 151, 452-468. https://doi.org/10.1046/j.1365-246X.2002.01765.x 